\title{
A study of saline incursion across an inter-tidal zone on Anglesey, Wales using airborne conductivity data
}

David Beamish

British Geological Survey, Keyworth, Nottingham, NG12 5GG, UK.

Near Surface Geophysics, 2012, 10, 171-184

Corresponding author:

David Beamish

British Geological Survey, Keyworth, Nottingham, NG12 5GG, UK

Email: dbe@bgs.ac.uk.

Tel: +44(0)1159363432

Fax: +44(0)115 9363261

Right running head: inter-tidal zone, saline incursion Anglesey Wales, airborne 


\begin{abstract}
This study considers fixed-wing airborne electromagnetic data obtained by a recent highresolution airborne geophysical survey across the island of Anglesey, Wales. The survey detected an extensive ( $\sim 10 \mathrm{~km}$ in length) highly conductive, near-surface zone across lowlying marsh and salt-marsh areas. The four frequency electromagnetic survey data enable a continuous assessment of subsurface conductivity variations across the inter-tidal zone and onshore into the Holocene sediments and bedrock. Inshore sea-water conductivities exceed $2000 \mathrm{mS} / \mathrm{m}$ but reduce across sandbank areas to a range of values, typically exceeding 500 $\mathrm{mS} / \mathrm{m}$. Saline incursion onshore is observed largely at lower values and at a range of scales extending to over $10 \mathrm{~km}$. Within defined salt-marsh areas, a main front of near-surface incursion can be mapped and extends several hundred metres inshore. The main body of subsurface saltwater incursion is largely confined to a trough containing Holocene deposits above Upper Carboniferous (Coal) Measures which were historically mined. The main conductive zone becomes more compact, both vertically and laterally, with increasing distance inland. Modelling of the data indicates that, onshore, the major concentrations of dissolved solids are confined to the upper $30 \mathrm{~m}$ within undulating subsurface zones. Historical tidal salt loading of the Holocene sediments may account for the main features detected within this low-lying and fault-bounded area now protected by tidal gates.
\end{abstract}




\section{INTRODUCTION}

Airborne electromagnetic (AEM) surveys to study onshore aquifers have become well established over the last decade (Smith et al., 2010). AEM aquifer studies in Europe are reported by Eberle and Siemon (2006) and Siemon et al. (2009). In Australia, the extensive land-use issue of salinisation has been the subject of major initiatives in the application of AEM surveys (Walker et al., 2004; Lawrie, 2008). The application of such surveys to both large and small scale coastal aquifers and processes across the inter-tidal zone is now becoming increasingly common.

A large scale project was undertaken by the USGS in relation to the Everglades National Park, Florida. The results of the surveys are given by Fitterman and Deszcz-Pan (1998) and in subsequent publications. The main emphasis of the work was in relation to salinity conditions within the Everglade aquifer system. The studies benefited from the calibration of the airborne resistivity models using borehole geophysical logs to allow estimation of chloride content. AEM studies of subglacial valleys in Northern Germany have revealed that subsurface saline intrusion can be detected up to $5 \mathrm{~km}$ inland from the North Sea coast (Gabriel et al., 2003; Steuer et al., 2009). The paper by Gabriel et al. (2003) provides details of the interpretational difficulties of distinguishing pore salt-loading and clay mineral lithologies in coastal environments.

More recently, airborne electromagnetics was used to study the transitional coastal environment across the Venice Lagoon (Viezzoli et al., 2010). The authors note that studies of the coastal zone salt-freshwater exchange remain challenging and that AEM surveys can overcome many of the logistical obstacles and provide a homogeneous framework of information. AEM investigations of complex coastal aquifers in Denmark, in relation to salinity and groundwater management are reported by Kirkegaard et al. (2011). This latter publication is of relevance to the study presented here in that a number of the technical issues (e.g. near-surface electromagnetic shielding) related to AEM data in the presence of excessive (> $1000 \mathrm{mS} / \mathrm{m})$ conductivities are discussed.

Geophysical measurements provide volumetric estimates of total formation conductivity $\sigma_{t}$ or its reciprocal, resistivity $\rho_{\mathrm{t}}$. The use of formation (or bulk) conductivity to investigate the subsurface relies on an ability to understand the factors that control it in a given geological setting. The formation conductivity $\left(\sigma_{t}\right)$ of a clean (a rock matrix that is perfectly insulating) fully saturated formation is proportional to the conductivity $\left(\sigma_{\mathrm{f}}\right)$ of the fluid. The constant of proportionality is referred to as the formation factor. Assuming negligible clay content, an empirical relationship developed by Archie (1942) indicates that the bulk conductivity is related to pore fluid conductivity $\left(\sigma_{\mathrm{f}}\right)$, fractional porosity $(\phi)$ and degree of saturation (S) as the first term in the expression:

$\sigma_{\mathrm{t}}=\mathrm{a}^{\prime} \sigma_{\mathrm{f}} \mathrm{S}^{\mathrm{n}} \phi^{\mathrm{m}}+\sigma_{\mathrm{s}}$ 
where a' is an empirically determined constant and S is the fluid-filled fraction of the pore space with an exponent (n) of about 2. The porosity exponent (m) is also an empirically determined parameter that depends on the geometric factor of grain shape and packing. In practice, even the cleanest formations contain small amounts of clay, or argillaceous bands, which can exert a significant influence on $\sigma_{t}$. A second term ( $\sigma_{\mathrm{s}}$ in equation 1$)$, due to mineral surface conduction can be introduced to allow for this (Glover et al., 2000; Kirsch, 2006). As can be seen from equation (1), the formation conductivity responds linearly to fluid conductivity. General relationships between fluid conductivity and salinity have been reported (Keller and Frischknecht, 1966, Fig. 8) and also between fluid conductivity and formation conductivity (e.g. Barker, 1982). In general, additional measurements are required to transform measured or modelled formation conductivities into estimates of salinity levels. Additional control is also required to distinguish between fluid conductivity contributions and those due to clay component litholologies (e.g. Gabriel et al., 2003).

Onshore ground electrical and electromagnetic geophysical measurements related to saline conditions at coastal and wetland locations in the UK are reported by Barker $(1982,1990)$ and McDonald et al. (1998). Ground geophysical investigations of the coastal zone of the Welsh mainland in the vicinity of Anglesey are reported by Obikoya and Bennell (2008). The geoelectrical surveys conducted by Barker (1982) along the east-coast of England (South Humberside) are of particular relevance here. High conductivity saline pore fluids in the Chalk bedrock were interpreted as deriving from an ancient (Holocene, 6 ka BP) estuarine river connection. It was suggested that the later deposition of relatively impermeable silts may have effectively sealed the high salinity water in the Chalk.

Here we consider a coastal subset of a wider AEM survey data across Anglesey, Wales. The study area considered, although previously an inter-tidal zone, is currently protected by tidalgates. The area is not subject to significant amounts of groundwater abstraction. In the context of the whole Anglesey survey, the area was found to contain extensive and excessive conductivities confined to a specific geological lithology comprising post glacial (Holocene) deposits above Upper Carboniferous Coal Measures. A major portion of the study area is protected and conserved by having SSSI (Sites of Special Scientific Interest) and SAC (Special Areas of Conservation) status. Portions of the area are also National Nature Reserves. The main purpose of the present study is to provide an understanding of the extensive conductivity zone largely contained within the Holocene sediments. In addition, the near surface information on saline conditions has a number of potential uses in relation to the ecology of the coastal conservation areas (e.g. Moffett et al., 2010)

\section{GEOLOGY}


The island of Anglesey (Ynys Môn) lies off the northwest coast of Wales, separated from the mainland by the Menai Strait (Figure 1). Primary geological surveying was published in 1920 following the work of Greenly (1919). Because of the relative antiquity of this data, the island is currently undergoing re-mapping by the British Geological Survey (BGS). The airborne survey data are intended to assist with geological map revision and to establish environmental baselines (Beamish and Schofield, 2010).

Anglesey is a topographically low-lying island that displays complex bedrock geology. The Neoproterozoic rocks that underlie much of the island have been described in terms of three main terranes (crustal assemblages) separated by faults (Gibbons and Horák, 1990). These are overlain by a patchy Palaeozoic cover succession including remnants of an OrdovicianSilurian sedimentary marine basin, an Old Red Sandstone fluvial succession as well as Carboniferous limestone and coal measures. The Neoproterozoic assemblages (groups) are shown in the 1:250k geological map of Figure 1 and are discussed by Horák \& Gibbons (2000). The airborne magnetic data obtained from the survey have been used to investigate both the near-surface (largely concealed) Palaeogene dyke swarm and magnetic basement features in relation to the existing tectonic framework (Beamish and White, 2011).

The main focus of the present study concerns a major coastal conductivity anomaly contained within the $12 \times 13 \mathrm{~km}$ area shown in Figure 1. The central part of the area contains an Upper Carboniferous bedrock unit largely overlain by post-glacial (Holocene) sediments. The Holocene sediments, described as Tidal Flat Deposits, are indentified in Figure 1 using crosshatch. The geological units are described in more detail later.

\section{METHODOLOGY}

New high-resolution airborne geophysical coverage of the UK has been provided by a fixedwing surveying platform (e.g. Beamish and Young, 2009). The system provides magnetic, radiometric and frequency domain electromagnetic (EM) survey measurements. The present study considers the EM survey data only. The characteristics of the 4-frequency EM system (AEM-05) are described by Leväniemi et al. (2009). The basic specifications of the AEM-05 system mounted on the wing-tips of a deHavilland Twin-Otter aircraft are given in Table 1. Each of the four coil pairs are operated in the vertical coplanar coil configuration.

\begin{tabular}{|l|l|l|l|l|}
\hline Frequency, Hz & 912 & 3005 & 11962 & 24510 \\
\hline Coil spacing, m & 21.35 & 21.35 & 21.38 & 21.38 \\
\hline Magnetic moment, $\mathrm{Am}^{2}$ & 190 & 127 & 49 & 27 \\
\hline
\end{tabular}

Table 1. Technical specifications of the AEM-05 system. 
At the typical flight speed employed in the UK, the EM sampling rate of $4 \mathrm{~Hz}$ provides a typical across ground sampling of less than $15 \mathrm{~m}$ along each flight line. The full survey area is a polygon $\left(1198 \mathrm{~km}^{2}\right)$ contained within a rectangle of $44.6 \times 35.25 \mathrm{~km}$ encompassing the whole island and a coastal zone of the mainland (Fig. 2). The survey flight direction (N-S) was chosen to intersect two dominant geological trends. Flight line spacing was $200 \mathrm{~m}$ and 6,316 line-km of data were acquired during 6 flying days from 12 to 18 June 2009, inclusive. A nominal survey altitude of $56 \mathrm{~m}$ was adopted but over the built environment a regulatory flight altitude of $>200 \mathrm{~m}$ was required.

The frequency domain AEM data comprise coupling ratios (real or in-phase) and imaginary or in-quadrature) at each of the four frequencies. The methods by which these data are converted to models of apparent conductivity or estimates of true conductivity have been described in a wide-range of publications that often focus on helicopter-borne, towed-bird systems (e.g. Tølbøll and Christensen, 2006). In the case of fixed-wing systems, the studies by Beamish (2002, 2004a) provide assessments of transform and inversion methods applied to single frequency data to obtain estimates of half-space conductivity. The highest frequency provides the shallowest depth of investigation and the half-space conductivity assessments with decreasing frequency are used to assess the conductivity variations with increasing depth. The study by Beamish (2002) compares transform and non-linear inversion half-space estimation procedures. The former procedures can be considered a conservative estimation procedure in the presence of EM cultural perturbations that influence much of the UK survey data.

The half-space estimates are primarily used for mapping the distribution of conductivity values prior to multi-frequency inversion. All such estimates typically provide conductivity models with a validity that depends on a vertically uniform (1D) assumption. 1D modeling of the multi-frequency data acquired by the AEM-05 system, together with synthetic data, has been described by Leväniemi et al. (2009) and Beamish and Leväniemi (2010). Both few layer and multi-layer (Occam) procedures are discussed. The importance of the noise model in such procedures was noted by Tølbøll and Christensen (2006). Sensor noise floors for the AEM-05 four frequency system are in range 20 to 30 ppm (Leväniemi et al., 2009). The nonlinear drift and levelling procedures applied to the raw data then add a significant additional uncertainty that is survey, flight and line specific. In addition to the 'absolute noise' the data are assigned an additional relative error (e.g. 5\%) to account for errors introduced in the model allowing for the assumption of one dimensionality and additional (unknown) calibration factors (e.g. Tølbøll and Christensen, 2006).

The restricted depth of investigation in highly conductive environments is an issue for all electromagnetic methods. A review of airborne electromagnetic skin-depths across a range of uniform (half-space) conductivities is provided by Beamish (2004b). At the lowest frequency available here $(912 \mathrm{~Hz})$ plane-wave skin-depths range decrease from $52.7 \mathrm{~m}$ for a half-space conductivity of $100 \mathrm{mS} / \mathrm{m}$ to $16.6 \mathrm{~m}$ at a conductivity of $1000 \mathrm{mS} / \mathrm{m}$. The attenuation behaviour (at all frequencies) in the more conductive zones considered here limits the resolution of the subsurface conductivity distribution with depth. It is likely that as 
conductivities exceed $450 \mathrm{mS} / \mathrm{m}$ (providing a plane-wave skin depth of $25 \mathrm{~m}$ at $912 \mathrm{~Hz}$ ), that only the upper surfaces of the conductive zones are resolved in the models presented.

The half-space conductivity estimates at each of the 4 frequencies can be used to map the conductivity distribution across the whole survey area. Here the highest frequency ( $25 \mathrm{kHz})$ data with the shallowest depth of investigation (closest to outcrop) are used initially. In order to adequately map the behaviour of the onshore data, the data have first been cut to the coastline (defined by mean high tide). The resulting conductivity distribution is shown in Figure 2. A specific set of colour contours are used to illustrate the general behaviour of the features observed. Overlaid on the map are cross-hatch areas which denote the main urban population centres (and an associated high-fly condition) and the 1:250k fault lines for cross reference with the geological map (Fig. 1).

It can be noted that many of the formations are either resistive $(<2.5 \mathrm{mS} / \mathrm{m})$ or only moderately conductive $(<30 \mathrm{mS} / \mathrm{m})$. Given this general low conductivity background, the influence of a number of more elevated conductive features due to cultural artefacts can be traced across the area. A set of quasi-linear features (such as that labelled P) are associated with the main motorway and road system. The feature, labelled P, is understood to be a subsurface pipeline. Additionally, at the more local scale, a number of highly conductive 'bulls-eye' anomalies are observed with defined associations such as that due to an aluminium smelting works (labelled A) and a landfill (labelled L).

A number of the geological features produce strong gradients in the conductivity responses. These include those associated with the Carmel Head Thrust (CHF) in the north and boundaries between the Carboniferous Limestone (a relatively conductive unit) and its contacts with older (e.g. Cambrian) formations. The extensive outcrops of Ordovician sediments also appear as relatively conducting but internally a range of subtle inter-formation variations exist. The isolation of the results to mean high tide level also reveals a number of small areas of enhanced conductivities that would typically be associated with onshore saline incursion. The largest (in amplitude and extent) conductive feature discovered by the Anglesey survey is clearly that associated with the outline location of the Upper Carboniferous (Coal Measures) unit. As noted previously, the bedrock unit is covered by post-glacial superficial deposits largely contained within the low lying trough to the NW of the regional scale Berw Fault (BF, Fig. 2).

The scale and extent of the conductivity enhancement within the low lying Malltraeth Trough (an informal name) is thought to be exceptional in relation to knowledge gained from airborne conductivity results at other UK coastal locations. This large scale and highly conductive feature forms the basis for the present study. In order to examine the characteristics and special conditions giving rise to the feature, data within the two rectangular areas shown in Figure 2 are examined in more detail. The outer rectangle is $12 \mathrm{x}$ $13 \mathrm{~km}$ and contains a significant portion of the inter-tidal coastal zone that may influence the conductivity distribution observed. As is further discussed below, at-surface seawater access to the onshore area is controlled by tidal gates and an engineered canal carries the Afon 
(river) Cefni across the marsh to the sea. The route of the canal can be seen as the thin high tide contour crossing the main conductive zone in Figure 2.

\section{RESULTS}

\section{Background}

Information across the study area has been assembled using a high resolution (5 m grid cell size) and accurate ( $1 \mathrm{~m}$ ) DTM. The data are best viewed looking north-east along the axis of the trough and centred on the escarpment associated with the Berw Fault. Figure 3 shows the bedrock geology and the main unit of superficial deposits (in cross-hatch) overlaid on the DTM. The coastal zone is identified by a blue contour denoting mean high-tide and a red contour denoting mean low-tide. The two tidal river courses are the Afon Cefni (AC) crossing the low lying Malltraeth Marsh and the Afon Braint (AB) located towards the southeast. In order to illustrate the extent of the low topographic level of the area, spot values of elevation are noted along the courses of the 2 rivers.

The Afon Cefni runs through Malltraeth Marsh in an artificial cut and is prevented from flowing into the marsh by embankments, on either side of which are two Main Drains which discharge into the estuary through tidal gates. An aerial view, looking west, across the tidal gates and estuary is shown in Figure 4. The image was taken at survey height elevation while flying one of the N-S survey lines. The deep channel of the Afon Cefni can be seen along the north western margin of the estuary. Current sediment transport and landform development across the area is discussed by Packham and Liddle (1970).

In the south-east, the Upper Carboniferous unit is bounded by the steeply inclined Berw Fault (BF, Fig. 3) and Cambrian units. The Carboniferous unit was significantly influenced by the Late Devensian Ice Sheet as described by Philips et al. (2010). A local trough abutting the harder rock to the south-east of the Berw Fault appears to have developed in response to subglacial erosion. Overlying the majority of the Upper Carboniferous unit is a thick sequence of Holocene (Tidal Flat) deposits. The mapping of these units, using borehole information across the trough, is currently ongoing. The typical Holocene sequences of multiple peat/organic sediment horizons interbedded within thick estuarine-marine sequences found in the NE of the Menai Strait are described by Roberts et al. (2011). Local borehole information within the study area is discussed later.

The Late Devensian and Holcene sea-level change in North Wales studied by Roberts et al. (2011) has provided one of the most comprehensive records of sea-level change in Europe. The data indicate that the final submergence of the Menai Strait occurred between 5.8 and 4.6 ka BP. The final breaching converted a flood-dominated estuary into a high energy tidal delta with extensive tidal scouring of pre-existing Holocene deposits. It is likely that the 
sediments within the Malltraeth Trough were also subject to similar tidal inundations particularly during high magnitude storm events.

The low lying nature of much of the coastal landform has resulted in a number of special scientific designations and areas of habitat protection. The area of land designated as a site of Special Scientific Interest (SSSI) is shown in outline form on a base topographic map in Figure 5. The main conservation sites comprise Malltraeth Marsh (MM) and Newborough Warren (NW). The latter site includes a coastal wooded area, in the west, and the Cefni Saltmarsh (CS). The offshore area, extending to the mean low-tide limit, is also designated as a Special Area of Conservation (SAC). The separate area in the west is the north-eastern limit of the Tywyn Aberffraw (TA) SSSI and contains a lake (Llyn Coron).

The construction of the sea wall and tidal gates during the 19'th century allowed drainage schemes to be developed to improve the agricultural performance of the marsh. The various refinements including the canalisation of the Afon Cefni in 1824 have resulted in a landscape of former meander loops. The same period saw a limited amount of coal mining to exploit the underlying coal measures. Information on the locations and extent of the underground workings is limited.

\section{Conductivity variations}

Figure 6a shows the distribution of half-space conductivity values (at $12 \mathrm{kHz}$ ) when the colour range is restricted to values of between 100 and $2000 \mathrm{mS} / \mathrm{m}$. According to the analysis of airborne EM skin depths reported by Beamish (2004b), the skin depths at $12 \mathrm{kHz}$ in material conductivities of $1000 \mathrm{mS} / \mathrm{m}$ or greater will be $4 \mathrm{~m}$ or less. The largest amplitudes in Figure 6a indicate areas where the depth of seawater is sufficient to provide a pure seawater response (i.e. the influence of underlying material is minimal). In offshore areas of shallower seawater and sandbanks, the amplitudes are modified and lowered. Typically, assuming identical underlying materials, the lowest offshore amplitudes would be associated with the shallowest depths of the water column. In the vicinity of the river estuaries, the assessment is more complex since mixing of salt and freshwater is also potentially involved. It should also be noted that data acquisition across the inshore sandbank area of Malltraeth Sands (e.g. Fig. 4 and 5) took place at different times on two different days.

The data of Figure 6a also reveal that significant, and localised, elevated conductivities are associated with the course of the Afon Braint (AB). There is an apparent pooling of higher conductivity values down the topographic gradient from the location of mean high-tide. Across Malltraeth Marsh, saline incursion extends continuously across the valley floor to beyond the location of mean high tide. In order to further investigate the more detailed effects associated with elevated conductivities; the same data are shown in Figure 6b with the colour range confined to values of between 1 and $50 \mathrm{mS} / \mathrm{m}$. Using this lower range of values a number of quasi-linear cultural perturbations associated with roads and a railway route become evident. The elevated conductivities ( $\sim 25 \mathrm{mS} / \mathrm{m}$ ) associated with the Carboniferous Limestone (Fig. 3) are now apparent. The conductivity of the coastal plain west of the Afon Braint, associated with Newborough Warren SSSI (Fig. 5) is clearly modified by saline incursion. The north-western edge of the elevated conductivities associated with the 
Carboniferous Limestone is closely associated with the contact between the Limestone and the Cambrian Monian Supergroup to the north-west (Fig. 3). An isolated anomaly within the Tywyn Aberffraw SSSI to the north-west appears associated with a lake (Llyn Coron, LC) and the response is typical of that associated with shallow lacustrine clays (e.g. Beamish and Farr, 2011).

The behaviour of the main saline incursion, especially within the near-surface, is of significance to the coastal portions of the SSSI areas. In order to illustrate this further and to examine the behaviour with depth, a more detailed $4 \times 4 \mathrm{~km}$ area (the rectangle shown in Fig. 6b) covering the main inner estuary of the Malltraeth Sands is now considered. In order to summarise the depth dependent behaviour, the $50 \mathrm{mS} / \mathrm{m}$ contour of the apparent conductivity data at all four frequencies is used. This contour level is the 'boundary' value used in the previous assessment (Fig. 6b); the contours are shown on a base topographic map in Figure 7. The two highest frequency contours ( 25 and $12 \mathrm{kHz}$ ) are associated with the shallowest depths of investigation and across the main area of the Newborough Warren SSSI; the contours can be used to infer the main boundary of saline incursion beneath the salt marsh and dune system. To the NW of the Afon Cefni, the contours track the general behaviour of the coastline. Towards the south, a large scale effect is observed at the two lowest frequencies in association with the Berw Fault (BF). The contour level of $50 \mathrm{mS} / \mathrm{m}$ at both frequencies tracks the location of the fault both within this detailed area and beyond (e.g. Fig. 6b). Towards the SW, approaching the coast, a slight but persistent deviation from the strike of the Fault is apparent. In order to investigate the distinct frequency-dependent behaviour a conductivity cross-section was obtained along the $2 \mathrm{~km} \mathrm{N-S}$ profile (A-A') shown in Figure 7. The profile starts in the centre of Malltraeth Sands and extends southwards beyond the Berw Fault. Also to the south of the Berw Fault is a lithological contact between the Upper Carboniferous unit and the Cambrian Gwana Group formation (Fig. 3).

\section{Conductivity cross-section}

The 4-frequency EM data along the $2 \mathrm{~km}$ profile were inverted using a 1D Occam multi-layer procedure offering regularised, smooth models in the vertical direction (e.g. Farquharson et al., 2003). Such models do not detect interfaces, or recover 'true' layer conductivity values; however they are particularly useful in situations where the number of layers is unknown and/or the layers vary significantly across a profile. The procedure, as applied to the airborne data considered here, is further discussed by Leväniemi et al. (2009). Each 1D model comprises a uniform set of $4 \mathrm{~m}$ thick layers within the upper $60 \mathrm{~m}$, which then increase in thickness with depth. The chi-square expectation misfit for the 4-frequency data is 8 and the inversion misfit achieved depends on the noise model assumed for the data . Usually a number of inversion experiments are carried out in order to judge the noise levels in relation to the available control parameters of the inversion (e.g. reference models and degree of roughness, etc). These are discussed, for the scheme used here, by Zhang and Oldenburg (1999) and Farquharson et al. (2003). Following the sequence of inversion trials, a data error of 5\% in the EM coupling ratios was assumed. When conductivity cross-sections are 
constructed onshore through the inter-tidal zone, a wide dynamic range of conductivities is likely to exist together with a number of potential lateral gradients. These aspects make the assessment of inter-tidal zone cross-sections particularly difficult for $1 \mathrm{D}$ vertical assessments.

Figure 8 shows the observations and inversion results obtained across the $2 \mathrm{~km}$, S-N profile discussed above. The resulting conductivity cross-section obtained across the upper $60 \mathrm{~m}$ is shown in Figure 9. In the data fit plots of Figure 8, the EM coupling ratios span 3 orders of magnitude and a logarithmic scale is used. Some of the observed response variations are associated with undulations in flying elevation (Fig. 8c). The highly conductive sandbanks in the north provide in-phase coupling ratios approaching 10,000 ppm. In the south a transition to a highly resistive Cambrian lithology reduces the in-phase response at the lowest frequencies ( 0.9 and $3 \mathrm{kHz}$ ) to values that approach, then are contained within, the noise level of the system (e.g. $<50 \mathrm{ppm}$ ). The most spatially persistent misfit is observed in the quadrature component at the highest frequency (25 kHz, Fig. 8b). The principal of the Occam procedure is to provide a model that is consistent with the observations within a specified noise tolerance. The chi-square misfit, assuming 5\% data errors, is shown in Figure 8c. As expected, the misfit increases beyond the expection level of 8, over the highly resistive unit $(<1 \mathrm{mS} / \mathrm{m})$ in the south. The transition to misfit values below 8 across the highly conducting units in the north is due to the high level of model roughness applied to resolve the vertically compact, conductive zone towards the centre of the section (Fig. 9). This is due to the use of a trade-off parameter that attempts to balance the opposing effects of minimising the misfit and minimising the amount of structure in the model.

The conductivity cross-section obtained is shown in Figure 9, with a vertical exaggeration of $\mathrm{x} 10$ ). A logarithmic conductivity scale is used. The 1D results are approximate in the the region of lateral contrasts and due to the highly conducting nature of much of the crosssection, the inversion is unable to detect any specific thickness to the highly conducting material due to the limited depth of investigation. It is apparent that the maps of high frequency apparent conductivity provide information on at- and near-surface elevated conductivities as indicated in Figure 9. Just offshore there appears to be a significant lateral gradient in the conductivity transition to lower values shorewards. This is marked in Figure 9 by a colour-scale change at values $<750 \mathrm{mS} / \mathrm{m}$. The major gradient in the saline incursion is well defined by the data and extends some $\sim 300 \mathrm{~m}$ onshore, prior to the edge of the forested area (see Fig. 7). The high salinity zone influences all 4 frequencies but extending south is a thin conductive zone at depths in excess of $25 \mathrm{~m}$ that is only detected by the two lowest frequencies (e.g. Fig. 7). The nature of the smooth-model inversion procedure is that the 'true' vertical thickness of this zone is likely to be much less than $5 \mathrm{~m}$ (see for example, Leväniemi et al., 2009). The thin zone extends and terminates at the location of the Berw Fault as indicated by the behaviour of the low frequency contours in Figure 7. The contact between the relatively conducting Upper Carboniferous unit and the resistive Cambrian unit in the south is indicated. The behaviour observed in this cross-section is repeated on the parallel survey lines along a significant length of the onshore zone containing the Berw Fault in association with saline conditions. The concealed conductive feature is thus regional in 
scale. The zone appears to initiate at a depth of about $30 \mathrm{~m}$ in connection with the main body of saline incursion. The interpretation of the feature is unclear.

\section{Conductivity volume}

In order to summarise the main conductivity distribution through the inter-tidal zone and marsh area a $7 \times 5 \mathrm{~km}$ area (see Fig. 2) was selected. The rectangle contains the offshore area of the Malltraeth Sands and the main area of Maltraeth Marsh.

As discussed previously, the 4-frequency EM data within the 7 x $5 \mathrm{~km}$ rectangle were inverted using a 1D Occam multi-layer procedure. The same subsurface parameterisation was adopted as previously. The analysis provided $59061 \mathrm{D}$ assessments of the conductivity structure across the area. The chi-square expectation misfit for the 4-frequency data is 8 and, assuming data errors of $5 \%$, the data inversions returned a range of misfit values ranging from $\sim 8$ to 180 . The majority ( $51 \%$ of the total) were centred on the expectation value. In order to improve the confidence in the model, inversions with a chi-square misfit $>64$ were

rejected (13\% of the total). The remaining $1 \mathrm{D}$ models were then subjected to interpolation through a $3 \mathrm{D}$ volume of $7 \times 5 \times 0.08 \mathrm{~km}$ (i.e. to a depth of $80 \mathrm{~m}$ ). The voxel grid size was a uniform 50 x $50 \mathrm{~m}$ cell size for each of the $4 \mathrm{~m}$ thick model layers. Model conductivities range from about $0.5 \mathrm{mS} / \mathrm{m}$ to over $2000 \mathrm{mS} / \mathrm{m}$. A 3D visualisation of the conductivity distribution within the onshore/offshore volume was then performed. It should be noted that the depth of investigation across the area is highly variable. Within the centre of the trough model conductivities exceed $\sim 450 \mathrm{mS} / \mathrm{m}$ and locally exceed $1000 \mathrm{mS} / \mathrm{m}$ in the offshore area. At the lowest frequency of $912 \mathrm{~Hz}$, the plane-wave skin depth is $25 \mathrm{~m}$ in uniform material with a conductivity of $450 \mathrm{mS} / \mathrm{m}$.

A summary of the conductivity distribution obtained is shown as a 3D perspective view, looking NE, in Figure 10. The view has the sand bank area in the foreground. The information is shown draped below a reference surface DTM (Digital Terrain Model). The model is referred to mean sea level. As an aid to depth discrimation a virtual surface has been placed at a depth of $40 \mathrm{~m}$ below the reference surface. The virtual surface is a combined topographic and bedrock geology image. The trace of the at-surface Berw Fault and the high mean tide are also shown on the virtual surface. Five E-W conductivity cross-sections are shown at intervals of $1 \mathrm{~km}$. The conductivity colour range from 20 to $400 \mathrm{mS} / \mathrm{m}$ allows the main lateral extent of the enhanced conductivities associated with the sediments/bedrock to be identified. If the highest conductivities (in red) are examined first, it can be seen that the main conductive zone in the first 3 cross-sections (towards the NE) are largely associated with the upper $\sim 30 \mathrm{~m}$ and different subsurface attitudes of the zone can be observed on each of the cross-sections. In the final cross-section within the offshore sand-bank area, the high conductivities preclude resolution of the vertical extent of the conductive feature.Along both NW and SE margins of the trough, enhanced conductivities appear to be largely confined to the trough area. More detailed studies reveal some incursion of elevated conductivities into the formations to the NW of the trough. In contrast, and as noted previously, the highly resistive Cambrian formation in the $\mathrm{SE}$ appears to act as an impermeable unit. 
Figure 10 also shows the isovolume of conductivities in excess of $450 \mathrm{mS} / \mathrm{m}$ that can be traced along the main axis of the trough. Due to the limited depth of investigation within this zone, it is emphasised that it is only the lateral extent and upper surface of this feature that is well resolved by the data. The vertical extent is largely unresolved. The isovolume terminates prior to the NE limit of the study area and there is an apparent general broadening and thickening of the conductive volume coastwards. Onshore the main conductive zone is concealed but two at-surface, highly conductive areas are labelled A and B. A is located onshore, close to the location of a borehole (BH 1) discussed later and the larger area $\mathrm{B}$ is located within the sand-banks. Although the limitations of the vertical model resolution within the highly conducting offshore area, should again be noted, the highly conducting ( $>$ $1000 \mathrm{mS} / \mathrm{m}$ ) core of these two zones is confined to the upper $30 \mathrm{~m}$. This would indicate the major contribution to the bulk conductivities observed should be associated with the Holocene sediments. These are now discussed in more detail.

\section{Borehole control}

The main body of apparent saline incursion across Malltraeth Marsh has been investigated in relation to the post glacial superficial deposits that occur across the Malltraeth trough above the Upper Carboniferous unit. These deposits are currently being mapped in three dimensions using existing borehole logs and a new set of augered boreholes within the main area of Malltraeth Marsh. The superficial deposits across the 12 x $13 \mathrm{~km}$ study area are shown in Figure 11. In areas of no superficial cover the background DTM, used to provide shading, is coloured grey. The highest density of borehole $(\mathrm{BH})$ information is located in the $\mathrm{NE}$ where the main road infrastructure crosses the marsh area in the vicinity of BH 4 . The majority of boreholes are shallow and only the deepest borehole (BH 4) is referenced here. The information across this area reveals a thickening of the deposits towards the centre of the marsh with the borehole shown in Figure 11 (BH 4) recording a locally maximum depth to bedrock of $22 \mathrm{~m}$. Information to the SW of this area becomes sparse and the main depth to bedrock is established by the 3 boreholes shown in Figure 11 (labelled 1, 2 and 3) which record depths of between 20 and $33 \mathrm{~m}$.

Also shown in Figure 11 are the $50 \mathrm{mS} / \mathrm{m}$ apparent conductivity contours , discussed previously, for the highest $(25 \mathrm{kHz})$ and lowest $(0.9 \mathrm{kHz})$ frequencies across this larger area. Across the whole northwestern margin of the trough, the contours are associated with the coastline and the approximate limit of the superficial deposits. It can be seen that the $0.9 \mathrm{kHz}$ contour extends northeastwards as far as the high tide limit. The higher frequency contour continues about $2 \mathrm{~km}$ further to the northeast. The low frequency data are also subject to cultural perturbations which appear as closed contours including an elongate feature along the axis of the road (adjacent to BH 4). Along the southeast margin of the trough, the spatial separation of the high and low frequency contours (discussed previously) is maintained for about $5.5 \mathrm{~km}$ inland. Beyond this point, both contours follow the line of the Berw Fault for a further $\sim 5 \mathrm{~km}$. 
The 3 central deep boreholes (1, 2 and 3), drilled in the early $20^{\text {th }}$ century, provide the main control on the conductivity models developed from the airborne data across the main marsh area. The lithologies recorded are shown in Figure 12. The boreholes reveal a degree of spatial lithogical hetrogeneity. Typical sequences in the boreholes are unconsolidated clays, sands and gravels together with some consolidated mudstones. The maximum thicknesses of clay bands are $2.6 \mathrm{~m}$ (BH 1), $0.76 \mathrm{~m}(\mathrm{BH} 2)$ and $2.95 \mathrm{~m}$ (BH 3). The near-surface unconsolidated sand units are much thicker. The base stratigraphy in the two eastern-most boreholes comprises a final gravel/broken rock unit of significant thickness $(\sim 2 \mathrm{~m})$ consistent with a base glacial origin.

In order to summarise the conductivity models in the vicinity of the boreholes, a few-layered inversion of the EM data on the flight lines closest to each borehole was performed. Assuming that the data can be represented by discrete interface behaviour, a 2-layer above half-space model was assumed. This parameterisation allows the depth and thickness of the highly conductive (saline) second layer to be estimated. The non-linear iterative inversion procedure used here is discussed by Beamish (2002). The inversions reveal that the second layer conductivity is in excess of $1000 \mathrm{mS} / \mathrm{m}$ in the vicinity of BH 1 (see also Fig. 10) but reduces to values of $\sim 275 \mathrm{mS} / \mathrm{m}$ around the two more easterly boreholes. The conductive interval obtained by the analysis is summarised in Figure 12 by the vertical arrowed bars. Typically the upper depth to the conductive interval is the best resolved feature. The deepest conductive interval is observed in the central borehole (BH 2) and extends to a depth of $55 \mathrm{~m}$. The onset of the conductive interval occurs at depths between $7.8 \mathrm{~m}(\mathrm{BH} 1), 17 \mathrm{~m}(\mathrm{BH} 2)$ and $9.4 \mathrm{~m}(\mathrm{BH} 3)$ which are all located within the near-surface sandstone. In summary there appears to be no obvious lithographic control on the vertical extent of the highly conductive zone when it is assumed to exist as a single unit.

It is evident that the conductive zone extends into the upper surface of the Carboniferous bedrock. This may be expected given the potential reworking of the material by glacial

action. It is also possible that a single conductive zone may be an inappropriate model for the saline (assumed) contributions to the pore fluid content of the materials. It is possible to speculate that contributions to at least two-zones of increased salinity may exist over the depth range considered. The deeper clay units may act as a confining layer and separate upper and lower contributions to saline conditions. The upper zone would then represent the contributions of younger depositional processes than the older and deeper contributions extending into the bedrock. The resolution required to fully interpret the model results discussed here would require further borehole assessments. These would typically involve down-hole conductivity measurements and, potentially, isotopic (e.g. carbon-14) dating of the pore fluids (Hanshaw et al., 1965; Post et al., 2003).

\section{CONCLUSIONS}

The baseline airborne geophysical survey of Anglesey revealed a highly significant zone of enhanced subsurface conductivities associated with the low-lying Malltraeth Marsh area. The scale of the conductive feature appears exceptional in relation to the current (limited) knowledge gained from other UK coastal survey data sets. Inshore sea-water conductivities 
exceed $2000 \mathrm{mS} / \mathrm{m}$ but reduce across tidal sandbank areas. Within the near-shore tidal estuary of Malltraeth Sands, a complex spatial pattern of localised high conductivity (> $1000 \mathrm{mS} / \mathrm{m}$ ) variations exist (Fig. 6a). Onshore, relatively compact localised, elevated conductivities are associated with the course of the Afon Braint. There is an apparent pooling of higher conductivity values down the topographic gradient from the location of mean high-tide (Fig. $6 a)$. The main onshore conductive zone examined here is more closely associated with the thick sequence of Holocene sediments above Upper Carboniferous Coal Measures that underlie the Malltraeth Marsh and Sands. 1D modelling assessments across the intertidal zone reveal an apparently continuous zone of elevated subsurface conductivities that extend $\sim 2 \mathrm{~km}$ beyond the high tide limit. In detail the zone appears to be controlled along its SE margin by the Berw Fault (Fig. 9 and Fig. 11) and to a lesser degree by the contact with the impermeable Cambrian formation. Saline incursion across the SSCI conservation areas is well-defined at shallow depths by the higher frequency data (Fig. 6b, Fig. 9 and Fig. 11) and can be observed close to the surface up to $\sim 300 \mathrm{~m}$ onshore. It is presumed that such results provide a large-scale, continuous framework that may assist with general ecological understanding of the coastal area since salinity is one of the major habitat controlling factors in this area (Packham and Liddle, 1970).

In the geological context considered, the geophysical data provide no direct discrimination between elevated conductivities due to high clay-content and saline pore-water. Additional information has therefore been introduced using a limited number of boreholes that penetrate through the thick sequence of Holocene sediments to the Carboniferous bedrock. Given the lithologies encountered it is unlikely that there are sufficient thicknesses of clay materials to account for the bulk conductivities, locally exceeding $1000 \mathrm{mS} / \mathrm{m}$, observed in the onshore geophysical models across the majority of the area occupied by the sediments. The elevated conductivities continue into the bedrock to various depths (Fig. 12) although they become shallower and more compact with increasing distance inland (Fig. 10). In order to understand this behaviour, the potential reworking (and incision?) of the bedrock by late Devensian glacial action, as described by Phillips et al. (2010) may be considered. It has also been noted that the subsequent Holocene sea-level change in this area (Roberts et al., 2011) would have subjected the trough area to a series of tidal inundations. Such events would have provided salt-loading of the pore-fluids at various stages in the sedimentary development of the trough. Further understanding of the conductivity results would require additional borehole investigations and, possibly, dating of the pore fluids.

\section{ACKNOWLEDGEMENTS}

My thanks go to the reviewers who have assisted in improving the manuscript. Topographic base maps are reproduced from the OS by British Geological Survey with the permission of Ordnance Survey on behalf of the Controller of Her Majesty's Stationery Office, Crown copyright. All rights reserved. This report is published with the permission of the Executive Director, British Geological Survey (NERC). 


\section{REFERENCES}

Archie, G. E. 1942. The electrical resistivity log as an aid in determining some reservoir characteristics. Transactions of the American Institute of Mining, Metallurigical and Petroleum Engineers 146, 54-62.

Barker, R.D. 1982. Geophysical surveys near Goxhill, South Humberside. Proceedings of the Yorkshire Geological Society 44, 119-129.

Barker, R.D. 1990. Investigation of groundwater salinity by geophysical methods. In: Geotechnical and Environmental Geophysics, Vol. 2 (ed. S.H. Ward), Environmental and Groundwater Investigations in Geophysics, No. 5, 201-211.

Beamish, D. 2002. An assessment of inversion methods for AEM data applied to environmental studies. Journal of Applied Geophysics 51, 75-96.

Beamish, D. 2004a. 3D modelling of near-surface, environmental effects on AEM data. Journal of Applied Geophysics 56, 263-280.

Beamish, D. 2004b. Airborne EM skin depths. Geophysical Prospecting 52, 439-449.

Beamish, D. and Young. M. 2009. Geophysics of Northern Ireland: the Tellus effect. First Break 27, 43-49.

Beamish, D. And Schofield, D., 2010. HiRes airborne geophysical survey of Anglesey: a key dataset for unravelling complex geology and establishing an environmental baseline. GSA (Geological Society of America) Abstracts with Programs, Vol. 42, No. 1. 
Beamish, D. and Leväniemi, H., 2010. The canopy effect in AEM revisited: investigations using laser and radar altimetry. Near Surface Geophysics 8, 103-115.

Beamish, D. and Farr, G., 2011. Airborne geophysical data used to characterise groundwater dependant wetlands. Near Surface 2011 - 17th European Meeting of Environmental and Engineering Geophysics, Leicester, UK, 12 - 14 September 2011, Extended Abstract.

Beamish, D. and White, J.C. 2011. Aeromagnetic data in the UK: a study of the information content of baseline and modern surveys across Anglesey, North Wales. Geophysical Journal International 184, 171-190.

Eberle, D.G. and Siemon, B., 2006. Identification of buried valleys using the BGR helicopterborne geophysical system. Near Surface Geophysics 4,125-133.

Farquharson, C.G., Oldenburg, D.W. and Routh, P.S. 2003. Simultaneous 1D inversion of loop-loop electromagnetic data for magnetic susceptibility and electrical conductivity. Geophysics 68, 1857-1869.

Fitterman, D.V. and Deszcz-Pan, M. 1998. Helicopter EM mapping of saltwater intrusion in Everglades National Park, Florida. Exploration Geophysics 29, 240-243.

Gabriel, G., Kirsch, R., Siemon, B. and Wiederhold, H. 2003. Geophysical investigation of buried Pleistocene subglacial valleys in Northern Germany. Journal of Applied Geophysics 53, 159-180.

Gibbons, W. and Horák, J.M. 1990. Contrasting metamorphic terranes in northwest Wales. In: The Cadomian Orogeny, (eds R.S. D'Lemos, R.A. Strachan and C.G. Topley), Geological Society, London, Special Publications 51, 315-328.

Glover, P.W.J., Hole, M.J. and Pous, J. 2000. A modifed Archie's law for two conducting phases. Earth and Planetary Science Letters 180, 369-383.

Greenly, E., 1919. The geology of Anglesey. Memoir of the Geological Survey of the U.K.

Hanshaw, B. B., Back, W., Rubin, M., and Wait, R.L. 1965. Relation of carbon 14 concentrations to saline water contamination of coastal aquifers, Water Resource Research 1 , 109-114.

Horák, J.M. and Gibbons, W. 2000. Anglesey and the Lleyn Peninsula. In: Carney, J.N. (ed.) Precambrian Rocks of England and Wales (ed. J.N. Carney), Geological Conservation Review Series, No. 20, Joint Nature Conservation Committee, Peterborough, United Kingdom.

Keller, G.V., and Frischknecht F.C. 1966. Electrical methods in geophysical prospecting. Pergamon Press, Oxford, UK. 
Kirkegaard, C., Sonnenborg, T.O, Auken, E. and Jorgensen, F. 2011. Salinity distribution in heterogeneous coastal aquifers mapped by airborne electromagnetic. Vadose Zone Journal $10,125-135$.

Kirsch R. 2006. Petrophysical properties of permeable and low-permeable rocks. In: Groundwater geophysics - A tool for hydrogeology (ed. R. Kirsch). Springer, New York. ISBN: 3-540-29383-3.

Lawrie, K. 2008. To what extent can recent advances in salinity mapping and assessment create new salinity management and policy opportunities? 2nd International Salinity Forum. Salinity, water and society-global issues, local action, 2 April 2008, Adelaide Convention Cenre, Adelaide, Australia.

Leväniemi, H, Beamish, D., Hautaniemi, H., Kurimo, M. Suppala, I., Vironmäki, J., Cuss, D., Lahti, M. and Tartaras, E. 2009. The JAC airborne EM system AEM-05. Journal of Applied Geophysics 67, 219-233.

McDonald, R.J., Russill, N.R.W., Miliorizos, M. and Thomas J.W. 1998. A geophysical investigation of saline intrusion and geological structure beneath areas of tidal coastal wetland at Langstone Harbour, Hampshire, UK. Geological Society, London, Special Publications 130, 77-94.

Moffett, K.B., Robinson, D.A. and Gorelick, S.M. 2010. Relationship of Salt Marsh Vegetation Zonation to Spatial Patterns in Soil Moisture, Salinity, and Topography. Ecosystems 13, 1287-1302.

Obikoya, I. and Bennell, J.D. 2008. Geophysical investigation of the fresh-saline water interface in the coastal area of Abergwyngregyn. Proceedings of SAGEEP 2008, Philadelphia, Pennsylvania, SAGEEP 21, 559-567.

Packham, J.R. and Liddle, M.J. 1970. The Cefni salt marsh, Anglesey, and its recent development. Field Studies 3, 331-356.

Phillips, E., Everest, J. and Diaz Doce, D. 2010 Bedrock controls on subglacial landform distribution and geomorphological processes : evidence from the Late Devensian Irish Sea Ice Stream. Sedimentary Geology 232, 98-118.

Post, V.E.A., Van der Plicht, H. and Meijer, H.A. 2003. The origin of brackish and saline groundwaters in the coastal area of the Netherlands. Netherlands Journal of Geosciences / Geologie en Mijnbouw 82, 133-147.

Roberts, M.J., Scourse, J.D., Bennell, J.D., Huws, D.G., Jago, C.F. and Long, B.T. 2011. Late Devensian and Holocene relative sea-level change in North Wales, UK. Journal of Quaternary Science 26, 141-155.

Siemon, B., Christiansen, A.V. and Auken, E., 2009. A review of helicopter-borne electromagnetic methods for groundwater exploration. Near Surface Geophysics 7, 629-646. 
Smith, B.D., Abraham, J.D. and Lundstrom, S.C. 2010. Airborne electromagnetic surveys by the U.S. Geological Survey over concealed glacial aquifers, Central United States.

Proceedings of SAGEEP 2010, Keystone, Colorado, SAGEEP, 23, 126-137.

Steuer, A., B. Siemon, and Auken, E. 2009. A comparison of helicopterborne electromagnetics in frequency- and time-domain at the Cuxhaven valley in Northern Germany. Journal of Applied Geophysics 67, 194 - 205.

Tølbøll R.J. and Christensen N.B. 2006. Robust 1D inversion and analysis of helicopter electromagnetic (HEM) data. Geophysics 71, 53-62.

Viezzoli, A., Tosi, L., Teatini, P. and Silvestri, S. 2010. Surface water-groundwater exchange in transitional coastal environments by airborne electromagnetics: The Venice Lagoon example. Geophysical Research Letters 37, L01402

Walker, G., Cresswell, R., Munday, T. and Liddicoat, C. 2004. South Australian Salinity Mapping and Management Support Project: Final Report (Overall Project Summary Report), South Australia. Department of Water, Land and Biodiversity Conservation. Report, DLWBC 2004/39.

Zhang, Z. and Oldenburg, D.W. 1999. Simultaneous reconstruction of 1-D susceptibility and conductivity from electromagnetic data. Geophysics 64, 33-47. 


\section{Figure Captions}

Figure 1. Location map (inset) and simplified bedrock geology map of Anglesey, North Wales. Palaeozoic features are largely shown in grey. A 12 x $13 \mathrm{~km}$ rectangle indicates the main study area. Superficial (Tidal Flat) cover is indicated in cross-hatch.

Figure 2. Outline of Anglesey airborne survey area (outer polygon) and colour-contoured image of $25 \mathrm{kHz}$ apparent conductivity cut to coast (mean high tide). The yellow lines indicate major faults (1:250k) and labelled features are discussed in the text. CHF: Carmel Head fault, A: aluminium smelting works, P: concealed pipeline, BF: Berw Fault. Larger $12 \mathrm{x}$ $13 \mathrm{~km}$ rectangle (broken line) is main study area. Smaller 7 x $5 \mathrm{~km}$ rectangle is a more detailed study area.

Figure 3. 12 x $13 \mathrm{~km}$ study area shown as a perspective view looking NE based on an accurate DTM. Solid geology is defined in colour and the superficial (Tidal Flat) deposits are shown in cross-hatch. Two tidal rivers, the Afon Cefni (AC) and Afon Braint (AB) are indicated. BF is the Berw Fault. Mean low tide is shown in red and mean high tide is shown in blue. Numbers refer to spot heights (m above mean sea level) along the course of the two rivers.

Figure 4. View looking west from survey aircraft (flying north) showing Afon Cefni and inshore area of the Malltraeth Sands and tidal gates.

Figure 5. 12 x $13 \mathrm{~km}$ study area shown as a perspective view looking NE based on an accurate DTM. Overlaid with 1:50k topographic map. Green zones denote special areas of conservation (SSSI and SAC). TA: Tywyn Aberffraw, MM: Malltraeth Marsh, MS: Malltraeth Sands, CS: Cefni Saltmarsh, NW: Newborough Warren. Mean low tide is shown in red and mean high tide is shown in blue.

Figure 6. 12 x $13 \mathrm{~km}$ study area shown as a perspective view looking NE based on an accurate DTM. Shown with $12 \mathrm{kHz}$ apparent conductivity superimposed. BF: Berw Fault, AC: Afon Cefni, AB: Afon Braint. (a) Conductivity range from 50 to $2000 \mathrm{mS} / \mathrm{m}$. (b) Conductivity range from 1 to $50 \mathrm{mS} / \mathrm{m}$. LC: Llyn Coron. Rectangle (solid black line) is a $4 \mathrm{x}$ $4 \mathrm{~km}$ area of more detailed study.

Figure 7. 4 x $4 \mathrm{~km}$ area (see previous Figure) with base 1:50k topographic map. Coloured contours show apparent conductivity value of $50 \mathrm{mS} / \mathrm{m}$ at the 4 frequencies. BF: Berw Fault (dash line). A $2 \mathrm{~km}$ N-S profile A-A' is also shown.

Figure 8. Observed (OBS, symbols) and modelled (MOD, lines) 4-frequency coupling ratios along profile A-A’. (a) In-phase coupling ratios. (b) Quadrature coupling ratios. (c) Chisquare misfit (black symbols) and sensor elevation (red symbols).

Figure 9. Conductivity cross-section obtained across profile A-A'. A logarithmic colour scale is used. Vertical exaggeration is $\mathrm{x} 10$. 
Figure 10. 1D conductivity variations assembled across a 7 x $5 \mathrm{~km}$ area to a depth of $80 \mathrm{~m}$. Perspective view looking NE with all information draped beneath the topographic surface. Five E-W conductivity cross-sections are shown at intervals of $1 \mathrm{~km}$ using a colour range from 20 to $400 \mathrm{mS} / \mathrm{m}$. An isovolume of conductivities in excess of $450 \mathrm{mS} / \mathrm{m}$ is also shown together with the locations of 3 boreholes. A virtual surface (bedrock and topographic map with Berw Fault, BF) is placed at a depth of $40 \mathrm{~m}$.

Figure 11. 12 x $13 \mathrm{~km}$ study area with superficial deposits with shade provided by the DTM. Location of 4 boreholes and depth to bedrock are shown. Coloured contours (purple and cyan) show apparent conductivity value of $50 \mathrm{mS} / \mathrm{m}$ at 2 (highest and lowest) frequencies. BF: Berw Fault, solid black line. Rectangle is 7 x 5 km study area used in previous Figure.

Figure 12. Borehole logs from the 3 boreholes shown in previous Figure. The main zone of enhanced conductivity identified by inversion of the 4-frequency airborne data in the vicinity of the boreholes is indicated. 


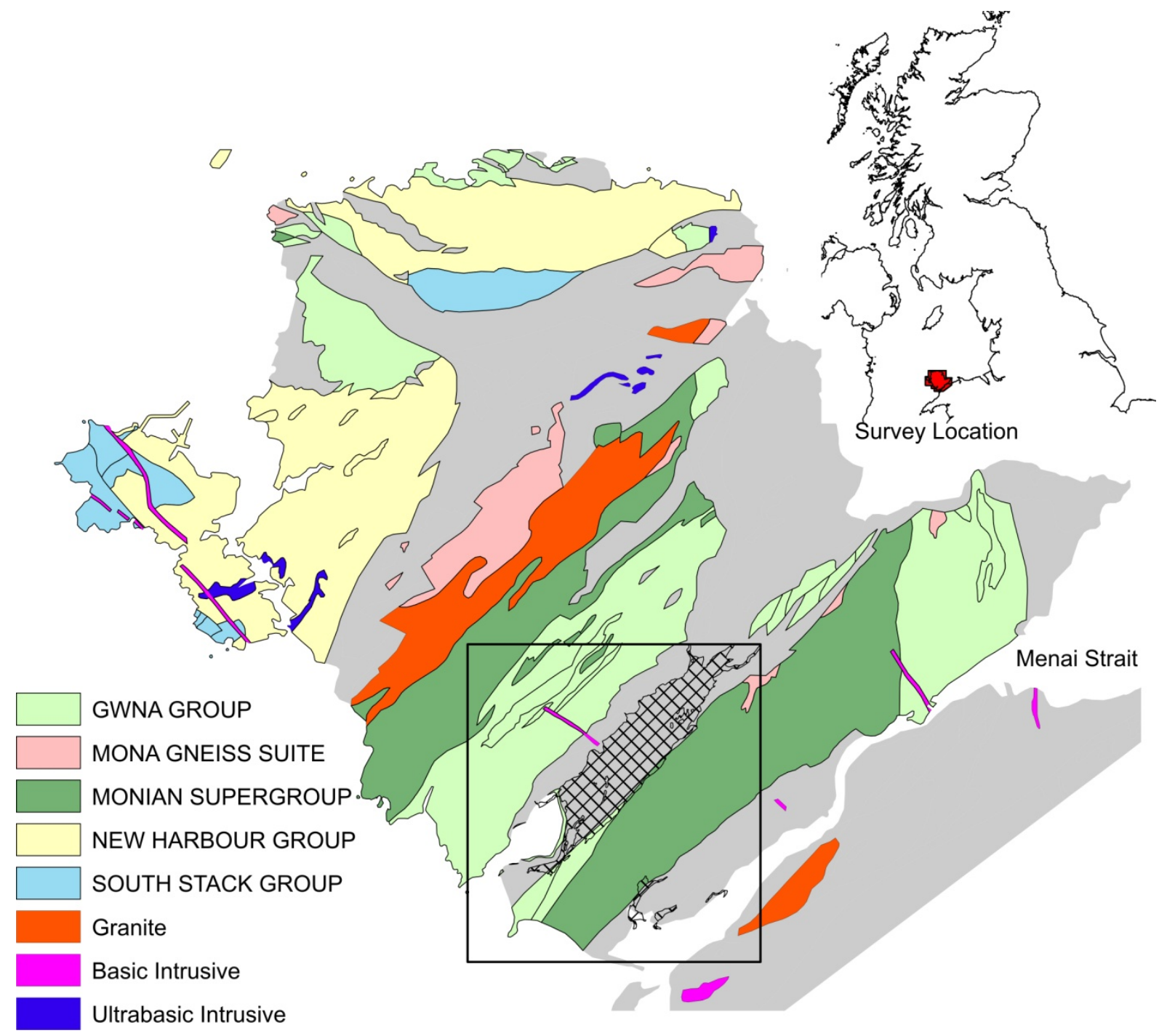

Figure 1

Figure 1. Location map (inset) and simplified bedrock geology map of Anglesey, North Wales. Palaeozoic features are largely shown in grey. A 12 x $13 \mathrm{~km}$ rectangle indicates the main study area. Superficial (Tidal Flat) cover is indicated in cross-hatch. 


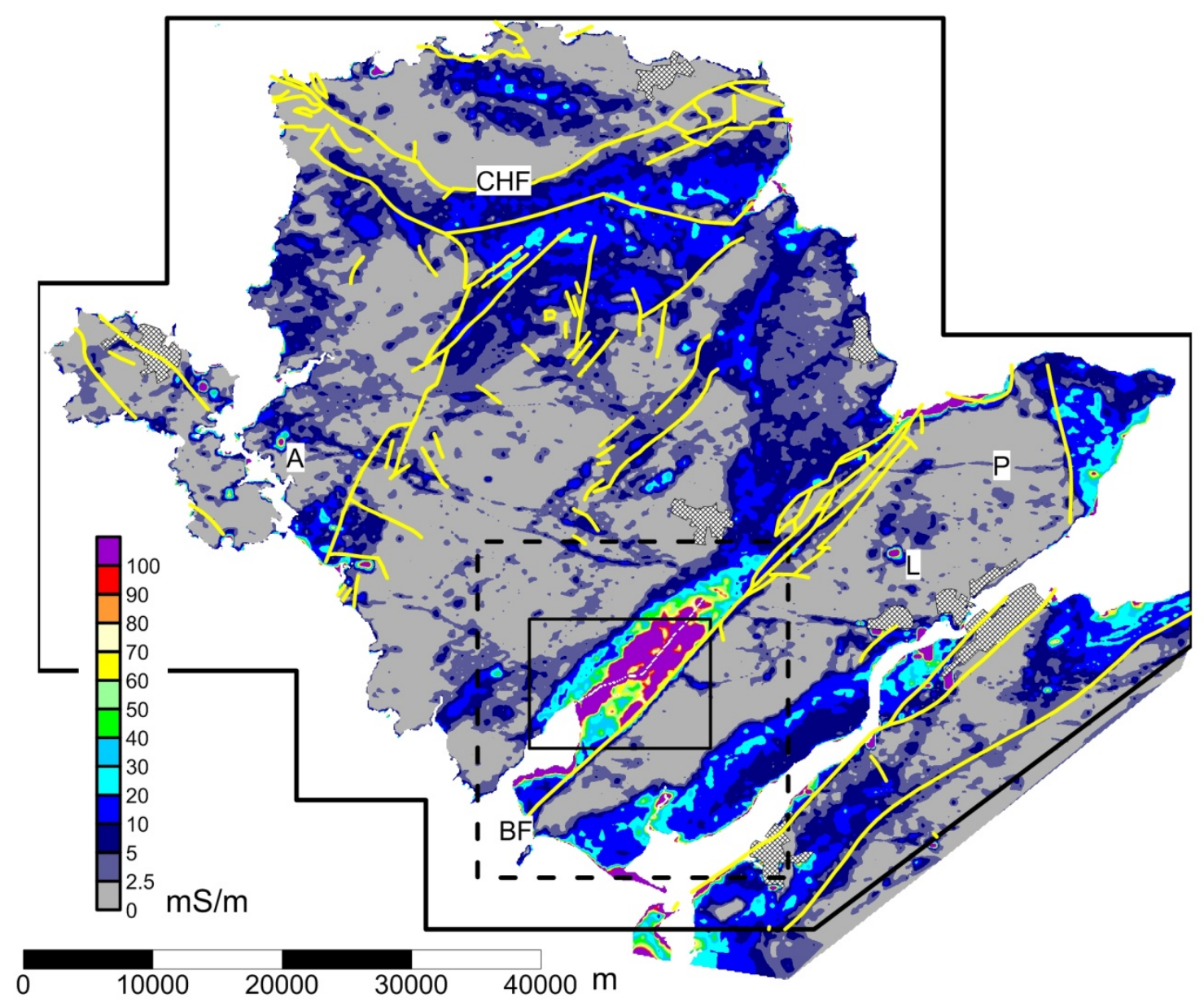

Figure 2

Figure 2. Outline of Anglesey airborne survey area (outer polygon) and colour-contoured image of $25 \mathrm{kHz}$ apparent conductivity cut to coast (mean high tide). The yellow lines indicate major faults $(1: 250 \mathrm{k})$ and labelled features are discussed in the text. CHF: Carmel Head fault, A: aluminium smelting works, P: concealed pipeline, BF: Berw Fault. Larger $12 \mathrm{x}$ $13 \mathrm{~km}$ rectangle (broken line) is main study area. Smaller 7 x $5 \mathrm{~km}$ rectangle is a more detailed study area. 


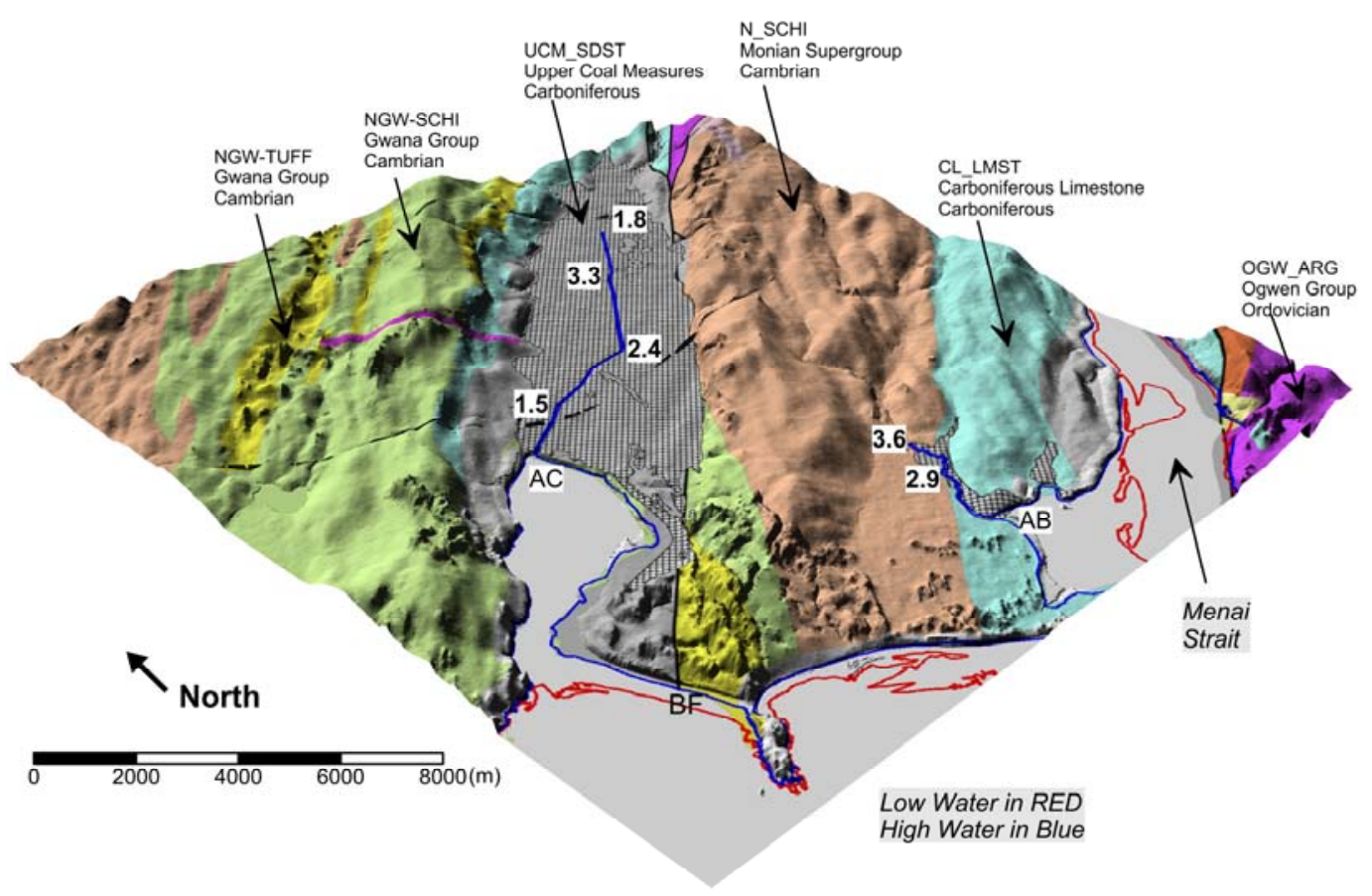

Figure 3

Figure 3. 12 x $13 \mathrm{~km}$ study area shown as a perspective view looking NE based on an accurate DTM. Solid geology is defined in colour and the superficial (Tidal Flat) deposits are shown in cross-hatch. Two tidal rivers, the Afon Cefni (AC) and Afon Braint (AB) are indicated. BF is the Berw Fault. Mean low tide is shown in red and mean high tide is shown 
in blue. Numbers refer to spot heights (m above mean sea level) along the course of the two rivers.

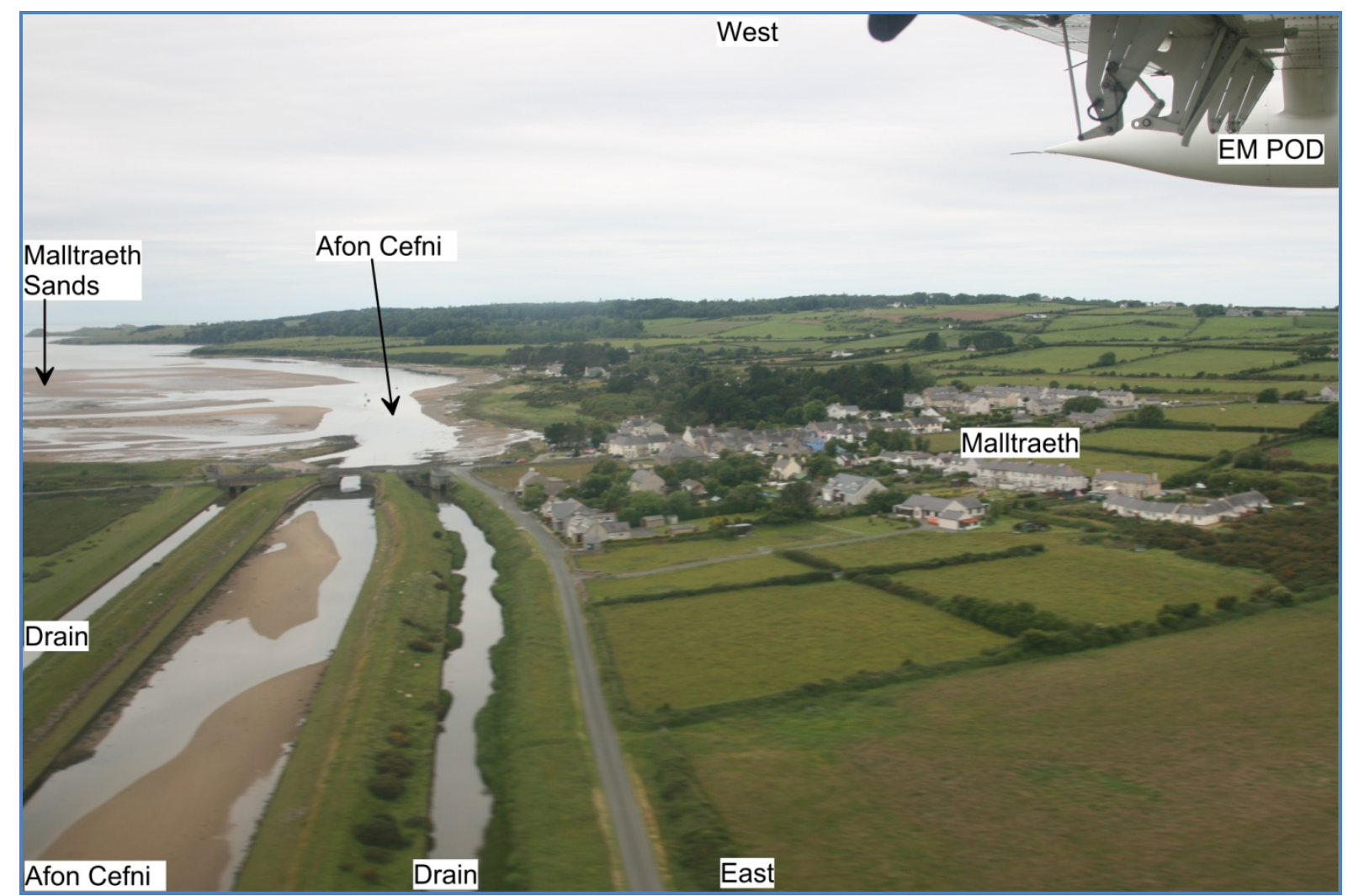

Figure 4

Figure 4. View looking west from survey aircraft (flying north) showing Afon Cefni and inshore area of the Malltraeth Sands and tidal gates. 


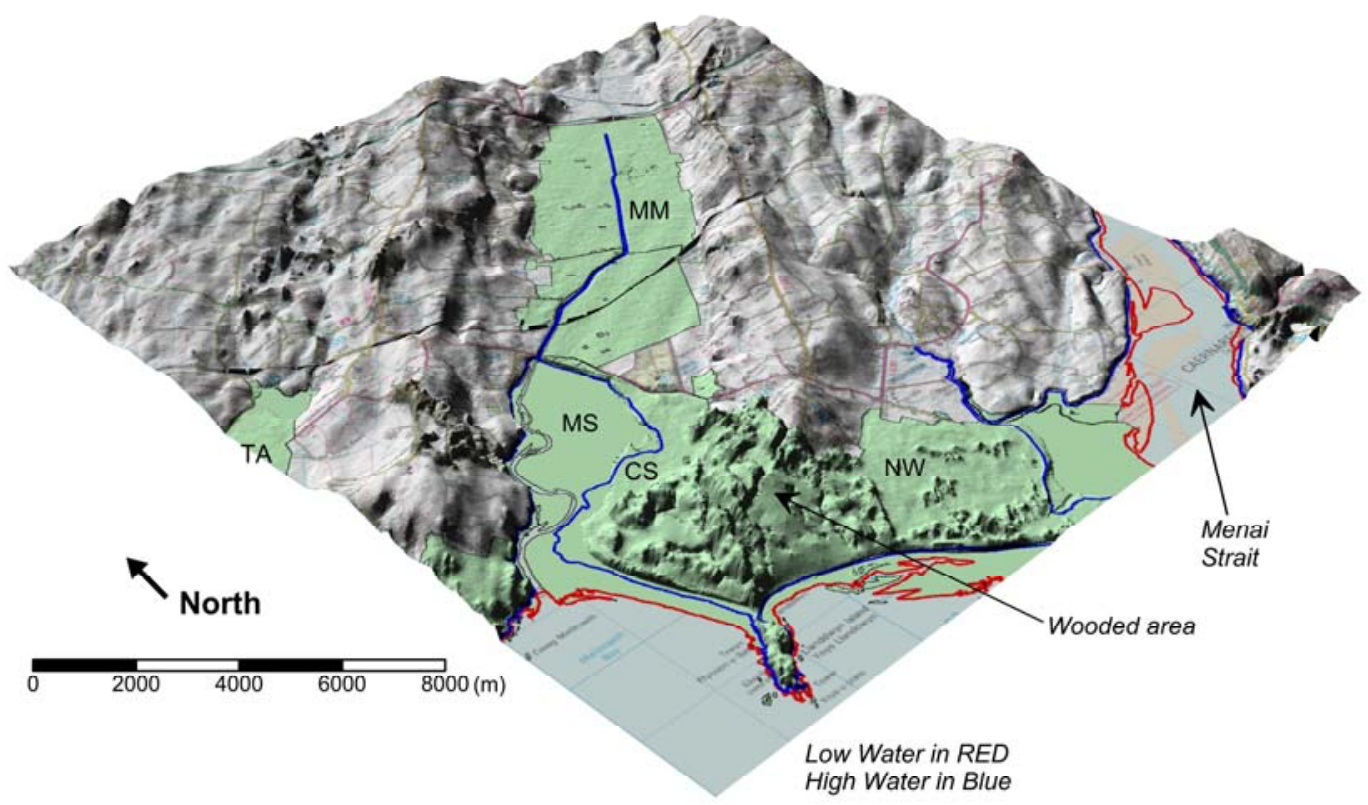

Figure 5

Figure 5. 12 x $13 \mathrm{~km}$ study area shown as a perspective view looking NE based on an accurate DTM. Overlaid with 1:50k topographic map. Green zones denote special areas of conservation (SSSI and SAC). TA: Tywyn Aberffraw, MM: Malltraeth Marsh, MS:

Malltraeth Sands, CS: Cefni Saltmarsh, NW: Newborough Warren. Mean low tide is shown in red and mean high tide is shown in blue. 

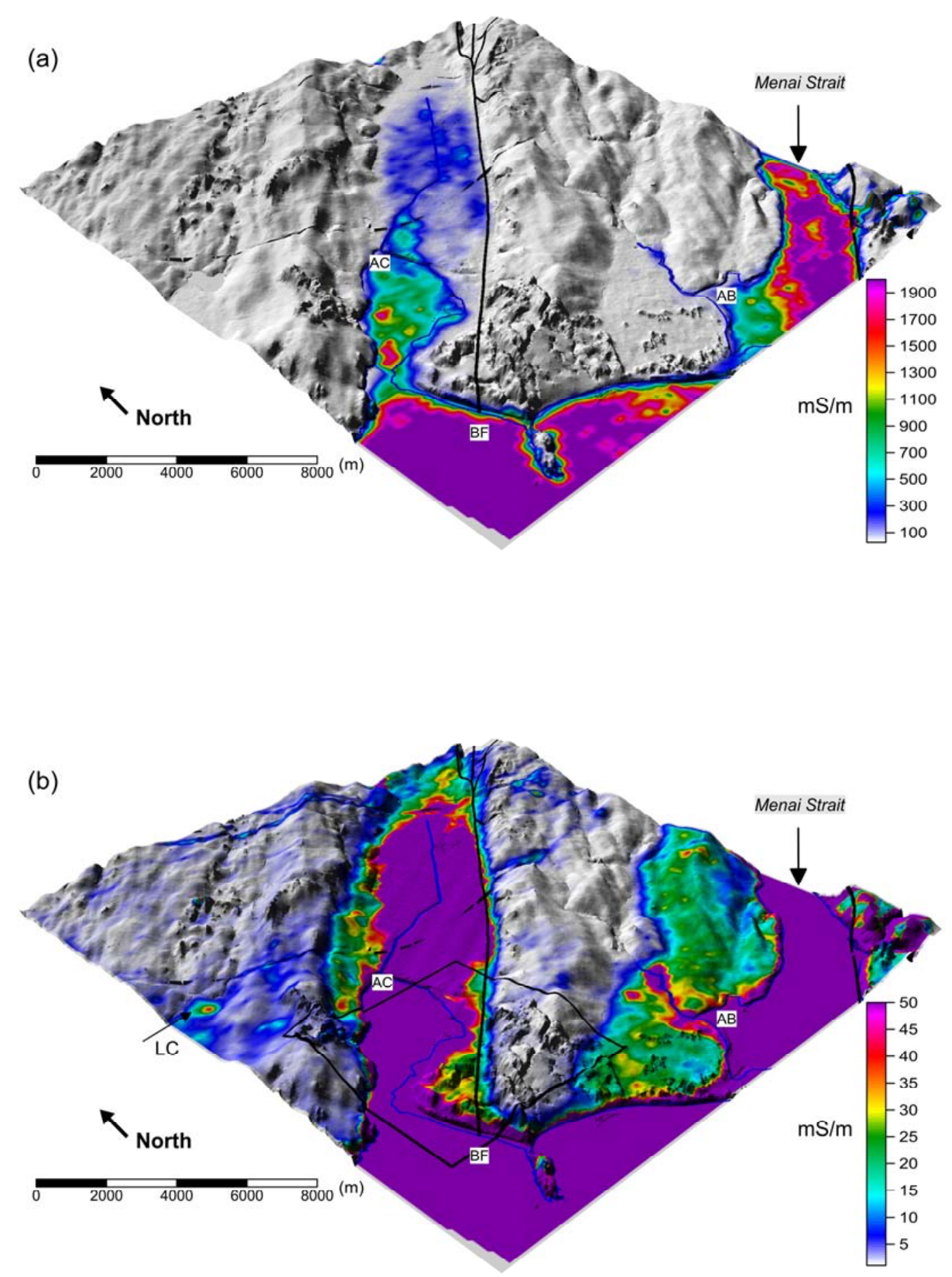

Figure 6

Figure 6. 12 x $13 \mathrm{~km}$ study area shown as a perspective view looking NE based on an accurate DTM. Shown with $12 \mathrm{kHz}$ apparent conductivity superimposed. BF: Berw Fault, AC: Afon Cefni, AB: Afon Braint. (a) Conductivity range from 50 to $2000 \mathrm{mS} / \mathrm{m}$. (b) Conductivity range from 1 to $50 \mathrm{mS} / \mathrm{m}$. LC: Llyn Coron. Rectangle (solid black line) is a $4 \mathrm{x}$ $4 \mathrm{~km}$ area of more detailed study. 


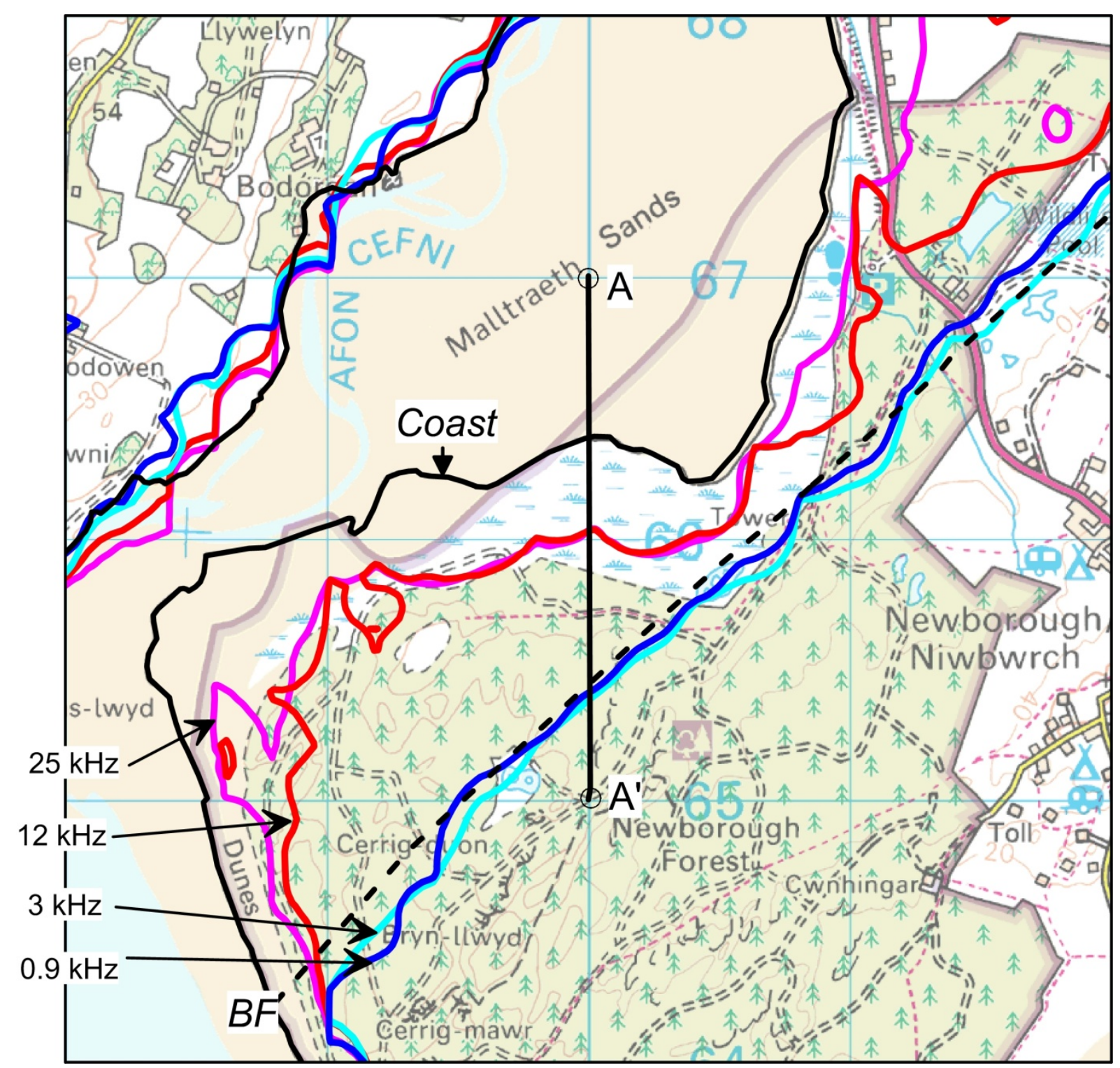

Figure 7

Figure 7. 4 x $4 \mathrm{~km}$ area (see previous Figure) with base 1:50k topographic map. Coloured contours show apparent conductivity value of $50 \mathrm{mS} / \mathrm{m}$ at the 4 frequencies. BF: Berw Fault (dash line). A 2 km N-S profile A-A’ is also shown. 

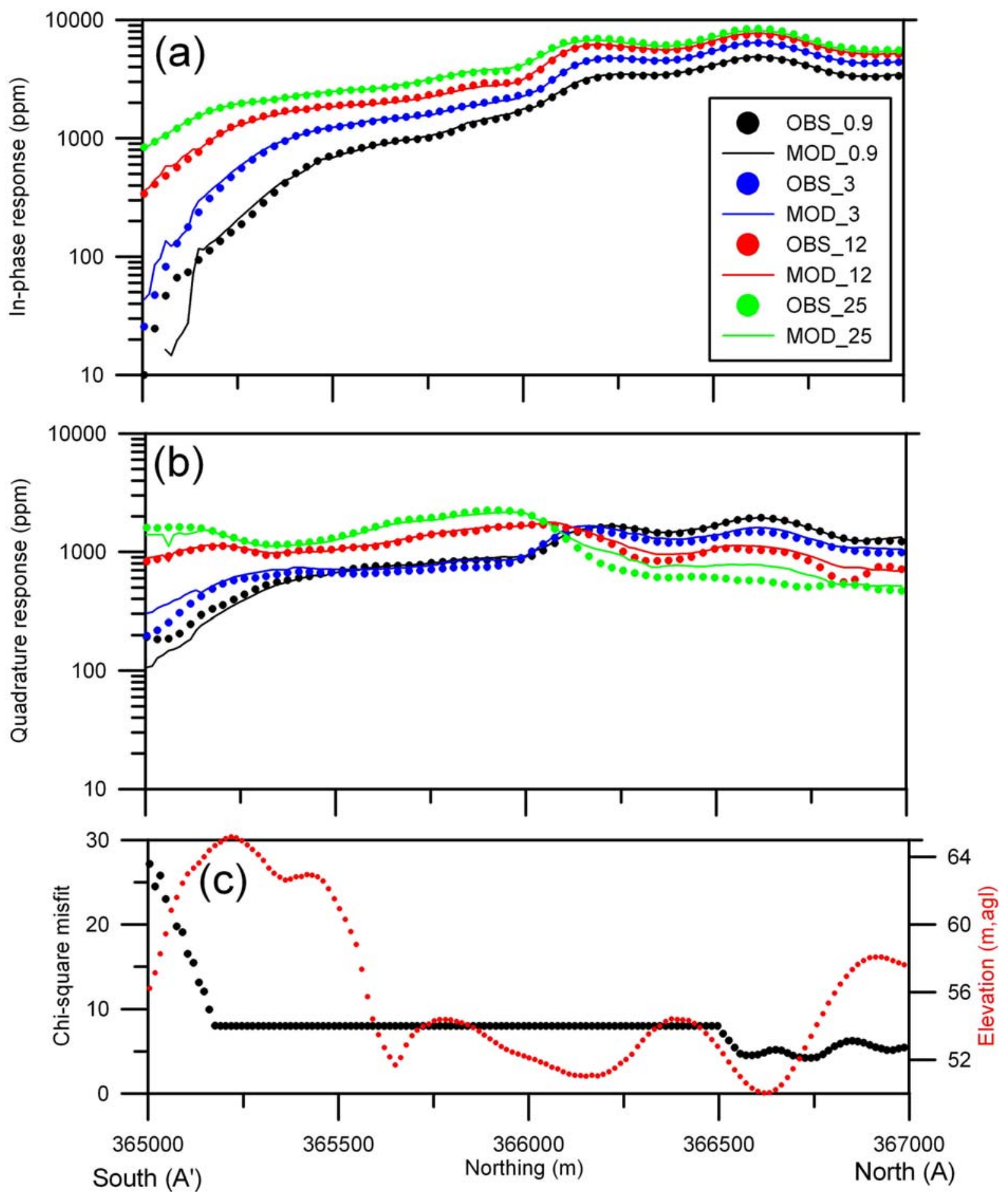

Figure 8

Figure 8. Observed (OBS, symbols) and modelled (MOD, lines) 4-frequency coupling ratios along profile A-A'. (a) In-phase coupling ratios. (b) Quadrature coupling ratios. (c) Chisquare misfit (black symbols) and sensor elevation (red symbols). 


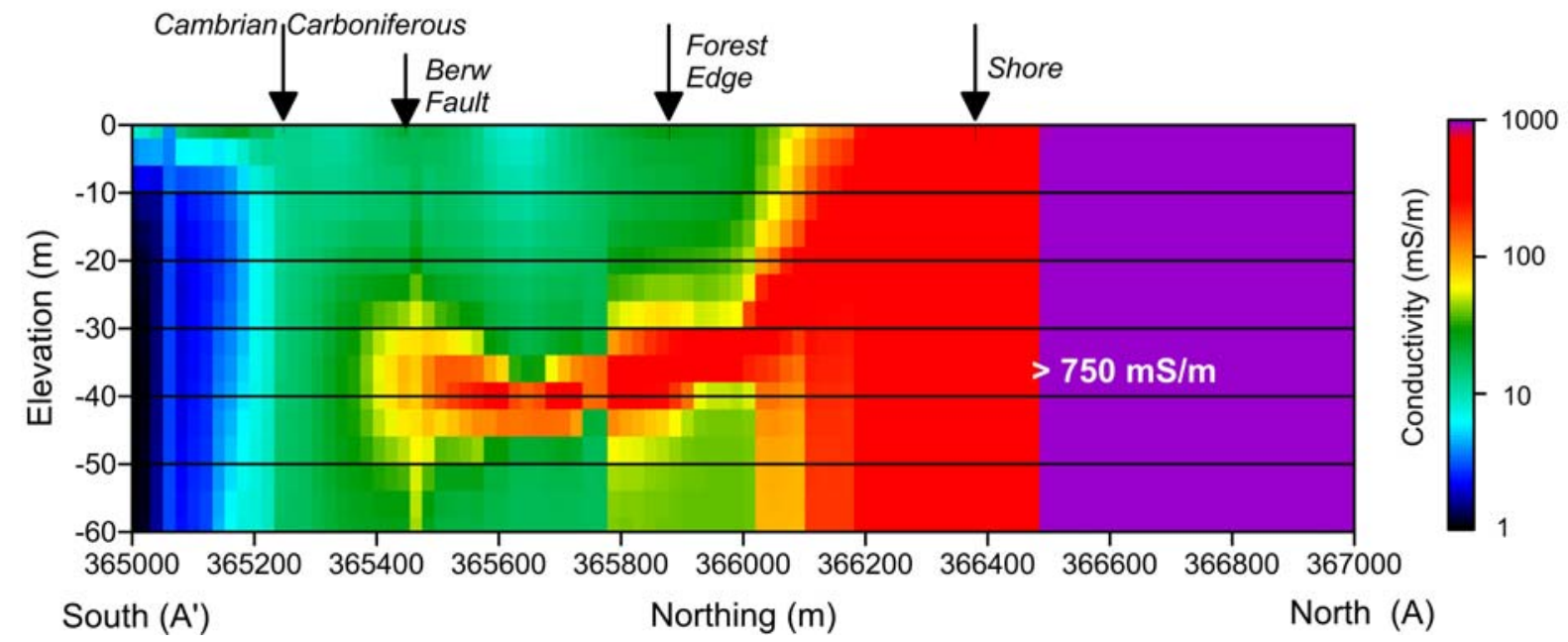

Figure 9

Figure 9. Conductivity cross-section obtained across profile A-A'. A logarithmic colour scale is used. Vertical exaggeration is $\mathrm{x} 10$. 


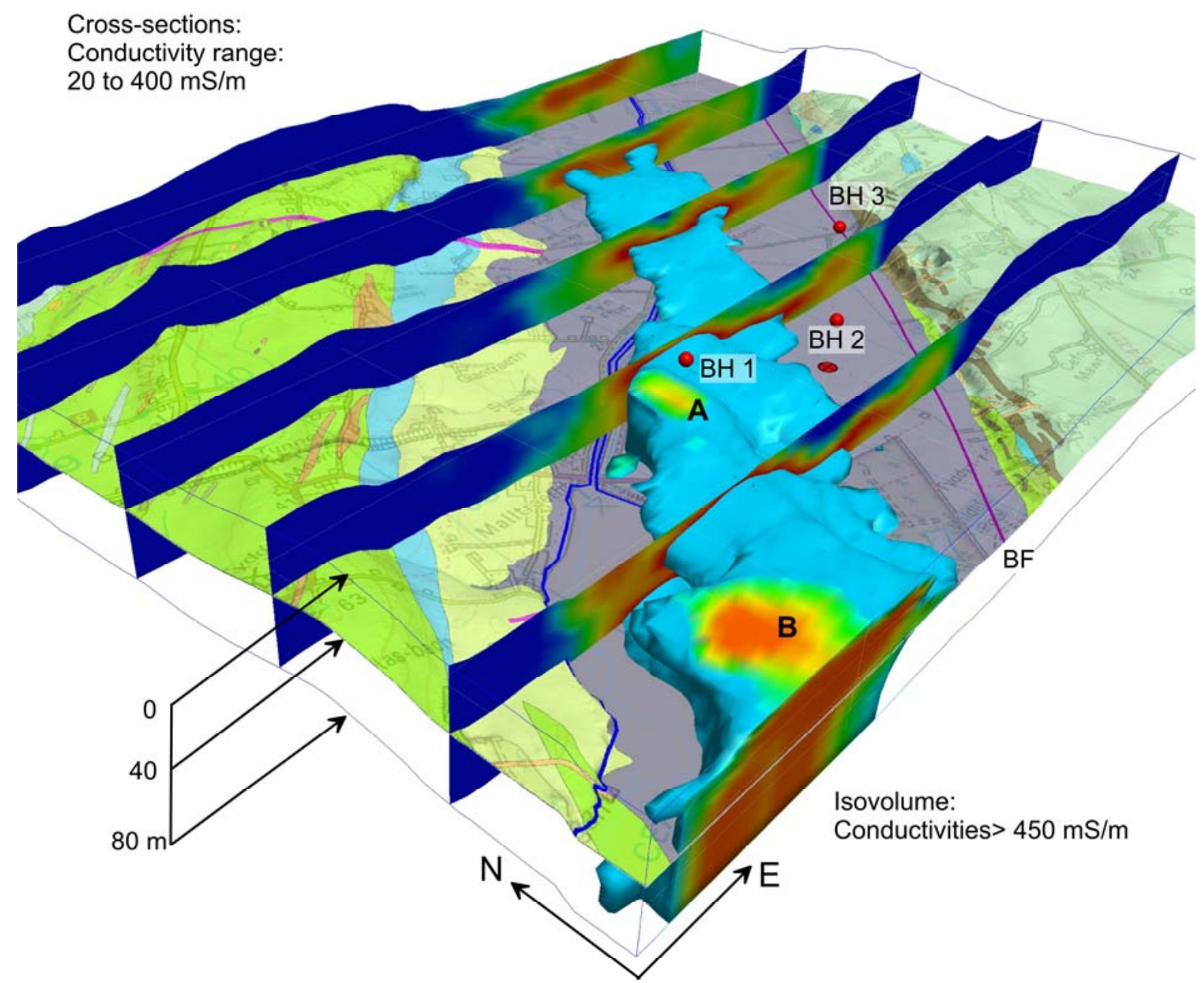

Figure 10

Figure 10. 1D conductivity variations assembled across a 7 x $5 \mathrm{~km}$ area to a depth of $80 \mathrm{~m}$. Perspective view looking NE with all information draped beneath the topographic surface. Five E-W conductivity cross-sections are shown at intervals of $1 \mathrm{~km}$ using a colour range from 20 to $400 \mathrm{mS} / \mathrm{m}$. An isovolume of conductivities in excess of $450 \mathrm{mS} / \mathrm{m}$ is also shown together with the locations of 3 boreholes. A virtual surface (bedrock and topographic map with Berw Fault, BF) is placed at a depth of $40 \mathrm{~m}$. 


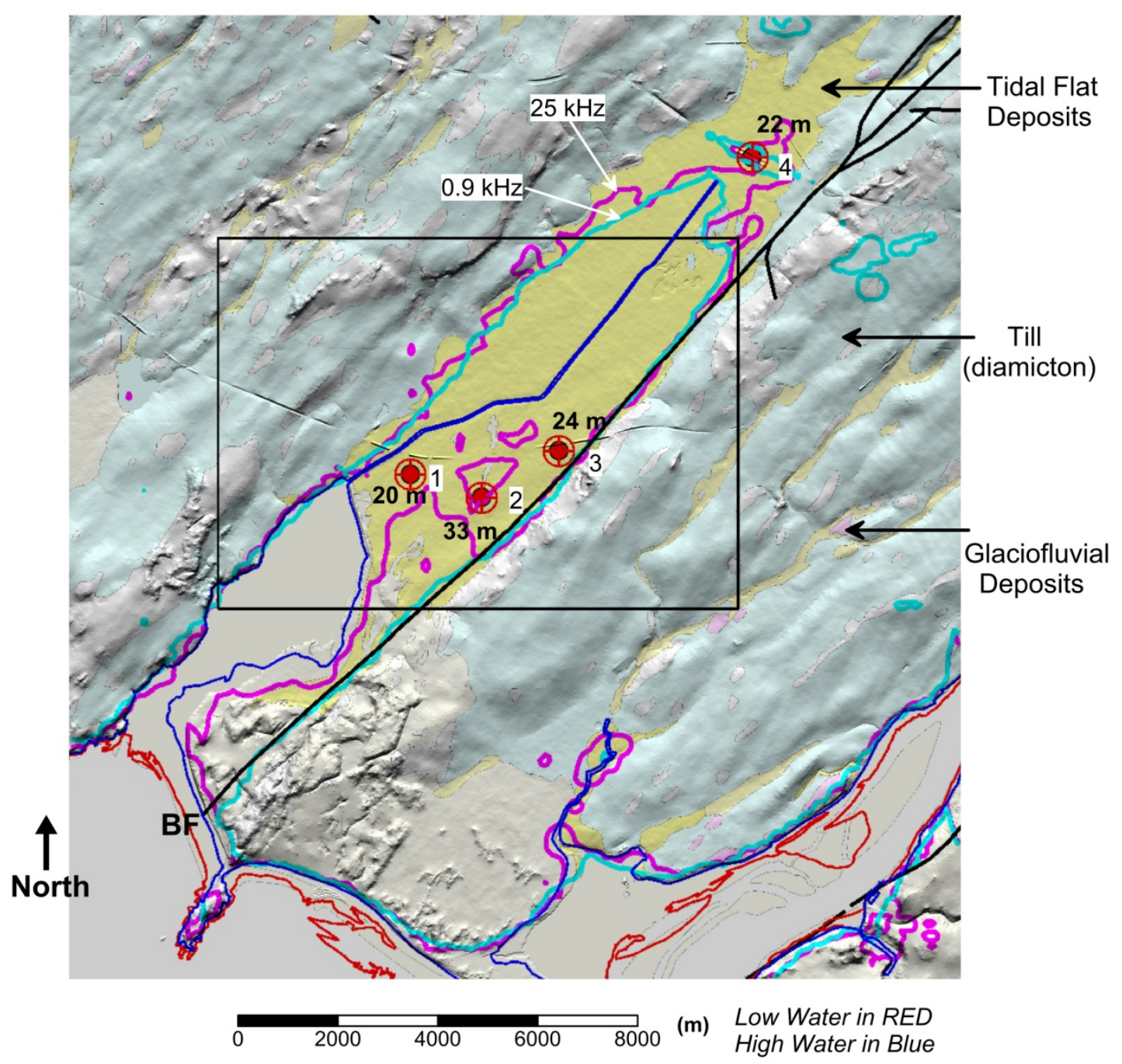

Figure 11

Figure 11. 12 x $13 \mathrm{~km}$ study area with superficial deposits with shade provided by the DTM. Location of 4 boreholes and depth to bedrock are shown. Coloured contours (purple and cyan) show apparent conductivity value of $50 \mathrm{mS} / \mathrm{m}$ at 2 (highest and lowest) frequencies. BF: Berw Fault, solid black line. Rectangle is 7 x 5 km study area used in previous Figure. 


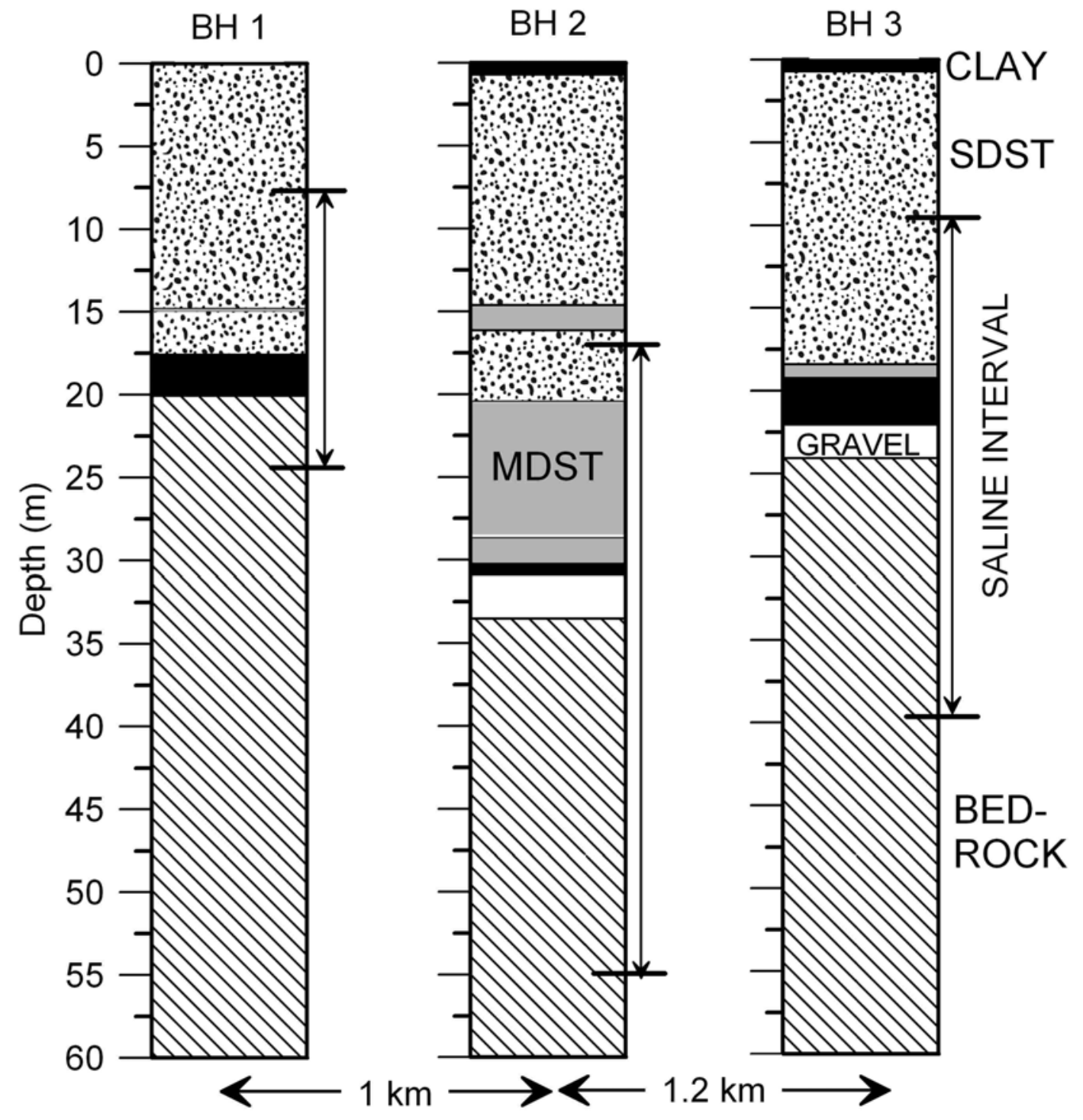

Figure 12

Figure 12. Borehole logs from the 3 boreholes shown in previous Figure. The main zone of enhanced conductivity identified by inversion of the 4-frequency airborne data in the vicinity of the boreholes is indicated. 